\title{
Phytoprotection
}

\section{Effects of aldicarb and fungicides on Pratylenchus penetrans populations, root rot and net blotch severity on barley}

\section{J. Kimpinski et H.W. Johnston}

Volume 76, numéro 1, 1995

URI : https://id.erudit.org/iderudit/706080ar

DOI : https://doi.org/10.7202/706080ar

Aller au sommaire du numéro

\section{Éditeur(s)}

Société de protection des plantes du Québec (SPPQ)l

\section{ISSN}

0031-9511 (imprimé)

1710-1603 (numérique)

\section{Découvrir la revue}

\section{Citer cet article}

Kimpinski, J. \& Johnston, H. (1995). Effects of aldicarb and fungicides on Pratylenchus penetrans populations, root rot and net blotch severity on barley. Phytoprotection, 76(1), 9-16. https://doi.org/10.7202/706080ar
Résumé de l'article

Les populations du nematode des lésions (Pratylenchus penetrans), lequel produit des lésions nécrotiques dans le cortex racinaire, ont été mesurées dans des parcelles expérimentales d'orge (Hordeum vulgare) en 1988,1989 et 1990. Les nematodes des lésions ont été les seuls nematodes endoparasites extraits des racines d'orge et ils étaient le groupe de nematodes dominant dans le sol. En se basant sur les moyennes des 3 années, les mesures de la pourriture racinaire, causée principalement par le Cochliobolus sativus et les Fusarium spp., ont augmenté de $27 \%$ selon l'échelle de croissance de Zadoks (ZGS) 30-32 en juillet, à 73\% à ZGS 70-72 à la fin d'août et au début de septembre. La rayure réticulée, causée par le Pyrenophora teres, a été supprimée par un traitement fongicide consistant en une application de carbathiine et de thirame lors du semis et une application foliaire de propiconazole. L'aldicarbe a supprimé les populations de nematodes des lésions dans le sol, dans tout le système racinaire, ainsi que dans les racines séminales et dans les racines du collet de l'orge. Les rendements ont augmenté d'environ 30\% lorsque l'aldicarbe et les fongicides étaient appliqués en traitement combiné. La densité des populations de nematodes des lésions était plus élevée dans les racines séminales que dans les racines du collet à ZGS 30-32 et ZGS 55-60. Les coefficients de corrélation entre les populations de nematodes et les rendements étaient souvent significativement négatifs $(P \leqslant 0,05)$. Il n'a pas été possible d'établir une relation significative entre les populations de nematodes des lésions dans les racines ou dans le sol et l'incidence de la rayure réticulée ou de la pourriture racinaire de

l'orge.
Ce document est protégé par la loi sur le droit d'auteur. L’utilisation des services d'Érudit (y compris la reproduction) est assujettie à sa politique d'utilisation que vous pouvez consulter en ligne.

https://apropos.erudit.org/fr/usagers/politique-dutilisation/ 


\title{
Effects of aldicarb and fungicides on Pratylenchus penetrans populations, root rot and net blotch severity on barley
}

\author{
Joseph Kimpinski and H. Winston Johnston ${ }^{1}$
}

Received 1993-10-13; accepted 1995-03-22

Population levels of the root lesion nematode, Pratylenchus penetrans, which produces necrotic lesions in the root cortex, were recorded in barley (Hordeum vulgare) in experimental plots during 1988, 1989, and 1990. Root lesion nematodes were the only endoparasitic nematodes recovered from barley roots and were the dominant nematode group found in the soil. Based on 3-yr averages, root rot ratings, caused primarily by Cochliobolus sativusand Fusarium spp., increased from $27 \%$ at Zadoks Growth Stage (ZGS) $30-32$ in July to $73 \%$ at ZGS 70-72 in late August and early September. Net blotch (incited by Pyrenophora teres) was suppressed by a fungicide treatment consisting of a seed application of carbathiin and thiram, and a foliar application of propiconazole. Aldicarb suppressed the populations of root lesion nematodes in the soil, in the total root system, and in crown and seminal roots of barley. Yields were increased by ca $30 \%$ where aldicarb and fungicides were applied as a combined treatment. Population densities of root lesion nematodes were much greater in seminal roots than in crown roots at ZGS 30-32 and 55-60. Correlation coefficients between nematodes and yield data were often negative and significant $(P \leq 0.05)$. There were no consistent trends in the numerical relationships between numbers of root lesion nematodes in roots or soil, and incidences of net blotch or root rot of barley.

Kimpinski, J. et H.W. Johnston. 1995. Effet de l'aldicarbe et de fongicides sur les populations de Pratylenchus penetrans et sur la sévérité des pourritures racinaires et de la rayure réticulée de l'orge. PHYTOPROTECTION 76: 9-16.

Les populations du nématode des lésions (Pratylenchus penetrans), lequel produit des lésions nécrotiques dans le cortex racinaire, ont été mesurées dans des parcelles expérimentales d'orge (Hordeum vulgare) en 1988, 1989 et 1990. Les nématodes des lésions ont été les seuls nématodes endoparasites extraits des racines d'orge et ils étaient le groupe de nématodes dominant dans le sol. En se basant sur les moyennes des 3 années, les mesures de la pourriture racinaire, causée principalement par le Cochliobolus sativus et les Fusarium spp., ont augmenté de $27 \%$ selon l'échelle de croissance de Zadoks (ZGS) 30-32 en juillet, à $73 \%$ à ZGS 70-72 à la fin d'août et au début de septembre. La rayure réticulée, causée par le Pyrenophora teres, a été supprimée par un traitement fongicide consistant en une application de carbathiine et de thirame lors du semis et une application foliaire de propiconazole. L'aldicarbe a supprimé les populations de nématodes des lésions dans le sol, dans tout le système racinaire, ainsi que dans les racines séminales et dans les racines du collet de l'orge. Les rendements ont augmenté d'environ $30 \%$ lorsque l'aldicarbe et les

1. Agriculture and Agri-Food Canada, Research Centre, Charlottetown, Prince Edward Island, Canada C1A 7M8. Contribution No. 800 
fongicides étaient appliqués en traitement combiné. La densité des populations de nématodes des lésions était plus élevée dans les racines séminales que dans les racines du collet à ZGS 30-32 et ZGS 55-60. Les coefficients de corrélation entre les populations de nématodes et les rendements étaient souvent significativement négatifs $(P \leq 0,05)$. II n'a pas été possible d'établir une relation significative entre les populations de nématodes des lésions dans les raciries ou dans le sol et l'incidence de la rayure réticulée ou de la pourriture racinaire de l'orge.

\section{INTRODUCTION}

The root lesion nematode, Pratylenchus penetrans (Cobb), is found commonly on barley (Hordeum vulgare L.) produced in the Maritime region (Kimpinski etal. 1989). This nematode species can occur concurrently on barley infected by Cochliobolus sativus (Ito \& Kurib.) and several Fusarium spp., the causal agents of common root rot, and Pyrenophora teres (Drechs.), causing net blotch, the main foliar disease pathogen (Johnston 1976). Previous studies on Prince Edward Island indicated that grain yield of barley was increased when these organisms were suppressed with fungicides or nematicides (Clough and Johnston 1978; Johnston and MacLeod 1987; Kimpinski et al. 1987, 1989; Martin 1985).

Plant-parasitic nematodes are believed to usually interact with root fungal pathogens in disease complexes (Bergeson 1972), and positive correlations have been observed between root lesion nematodes and various cereal diseases incited by fungal agents (Andersen 1975; Benedict and Mountain 1956). However, correlation and regression analyses of data from previous work on Prince Edward Island did not show significant relationships between population levels of root lesion nematodes in roots or soil and severity of root or foliar diseases in barley (Kimpinski et al. 1989).

The economic loss of barley in the Maritime region by soil-borne nematode and fungal diseases prompted the initiation of this investigation and the objectives were : to determine the impact of chemical treatments on root lesion nematodes, on the severity of root rot and net blotch symptoms, and on resulting grain yields; to determine the population levels of root lesion nematodes in adven- titious (crown) and seminal roots of barley; and to determine if correlations exist between soil or root populations of root lesion nematodes and root rot or net blotch of barley.

\section{MATERIALS AND METHODS}

The experimental sites for 1988,1989 , and 1990 were located on an Agriculture and Agri-Food Canada Research Branch property located at Harrington, Prince Edward Island $\left(46^{\circ} 21^{\prime} \mathrm{N} 63^{\circ} 11^{\prime} \mathrm{W}\right)$. The soil type was a fine sandy loam (ca 70\% sand, $20 \%$ silt, $10 \%$ clay, $2.5 \%$ organic matter; $\mathrm{pH}$ range of 5.8-6.0), and the previous crop was soybean (Glycine max L. cv. Maple Amber). In the spring of each year, the soil was tilled and $340 \mathrm{~kg} \mathrm{ha}^{-1}$ N-P-K fertilizer (17-17-17) was incorporated to a depth of $12 \mathrm{~cm}, 2 \mathrm{~d}$ before seeding. Seeding took place on 27 May 1988, 5 June 1989 and 2 June 1990, using the barley cv. Micmac. Plots, $4 \mathrm{~m} \times 2 \mathrm{~m}$, were established with rows $9.5 \mathrm{~cm}$ apart, at seeding rates of 220 , 180 and $190 \mathrm{~kg} \mathrm{ha}^{-1}$ in 1988, 1989 and 1990, respectively. When the crop seedlings were at the 2-5 leaf stage, chlorsulfuron [1-(2-chlorophenylsulphonyl)-3(4-methoxy-6-methyl-1,3,5-triazin2-yl)urea] was applied at $15 \mathrm{~g}$ a.i. $\mathrm{ha}^{-1}$ to control weeds. Yields at harvest, on 21, 26, and 28 September in 1988, 1989, and 1990, respectively, were estimated from the centre six rows of each plot. The 1000-kernel and hectolitre wt were determined from subsamples of the yield samples. Procedures for measuring emergence counts, 1000-kernel wt, hectolitre dry wt, and grain yields are outlined in Sylvester-Bradley et al. 1985. There were four treatments in each year: (i) untreated check; (ii) the nematicide aldicarb [2-methyl-2-(methylthio) propionaldehyde O-methylcarbamoyloxime] 15\% granular at 
$2.24 \mathrm{~kg}$ a.i. ha ${ }^{-1}$ broadcast and worked into the soil to a depth of $10 \mathrm{~cm}, 2 \mathrm{~d}$ before seeding; (iii) a fungicide seed treatment consisting of $167 \mathrm{~g} \mathrm{~L}^{-1}$ of carbathiin (5,6-dihydro-2-methyl-1,4oxathi-ine-3-carboxanilide) plus $148 \mathrm{~g} \mathrm{~L}^{-1}$ of thiram (tetramethylthiuram disulfide) at a combined rate of $0.55 \mathrm{~g}$ a.i. $\mathrm{kg}^{-1}$ seed to control seed-borne and seedling diseases, and a foliar spray of propiconazole [(+)-1-[2-(2,4-dichlorophenyl)-4propyl-1,3-dioxolan-2-ylmethyl]-1H-1,2,4triazole] applied at a rate of $125 \mathrm{~g}$ a.i. ha $^{-1}$ at ZGS 37 and 55 (Zadoks et al. 1974) in mid-July and mid-August to control leaf disease; and (iv) combined applications of aldicarb and fungicides. The experimental design was a $2 \times 2$ factorial combination of treatments in randomized complete blocks with four replicates in each year.

Soil samples for nematode analysis were taken randomly from the experimental sites in 1988, 1989, and 1990, 1-2 d before aldicarb was applied. Soil samples and root samples combining crown and seminal roots were collected from all plots 1-2 d before grain harvest in each year. In 1989 and 1990, crown and seminal root samples were also taken from all plots at ZGS $30-32,55-60$, and 70-72 (24 July 1989 and 9 July 1990; 16 August 1989 and 7 August 1990; 13 September 1989 and 30 August 1990, respectively).

Soil samples from each plot consisted of randomly taking 20 cores in the rows, $15 \mathrm{~cm}$ in depth, using a $25-\mathrm{mm}$-diam soil probe. Each soil sample was mixed thoroughly, and a $50 \mathrm{~g}$ subsample was placed in a modified Baermann funnel (Barker 1985) for $7 \mathrm{~d}$ at $23^{\circ} \mathrm{C}$. For root samples, over 100 plants were removed with a spade from outside the centre six rows of each plot at each sampling date. The root samples were washed, and in 1989 and 1990, the root systems of 10 plants from each plot were divided into crown and seminal portions, bulked, and a 5-10 g subsample placed in the mist chamber (Hooper 1986) for $7 \mathrm{~d}$ at $23^{\circ} \mathrm{C}$. The same procedure was used for the combined crown and seminal root samples taken 1-2 d before harvest in each year. Root lesion nematodes recovered from the experimental plots were expressed as number $\mathrm{kg}^{-1} \mathrm{dry}$ soil or number $\mathrm{g}^{-1}$ dry root.

Root rot severity was assessed visually on subcrown internodes of plants in all $3 \mathrm{yr}$. This was done at the same time as sampling for nematodes in roots. The root rot severity ratings were based on 100 plant samples, and were derived from Eq. [1] (Ledingham et al. 1973).

$$
y=(2 a+5 b+10 c) / 10
$$

This method gives values of $0,2,5$ and 10 for healthy, slight, moderate, and severe disease categories, respectively. In 1988, only healthy and diseased ratings were categorized. The incidence of net blotch was determined visually at ZGS $40-45$ by estimating the percent of lamina area lesioned on the top two leaves from 10 plants in each plot (Horsfall and Cowling 1978). In 1989, minimal foliar disease occurred and no data were collected. At each sample date, the fungal pathogens responsible for the root rot were isolated from several host plants. Identifications were confirmed using the stereomicroscope and compound microscope for leaf and root infected by fungal pathogens.

Nematode data and disease severity data were transformed to logarithms and angles, respectively, and analyses of variance were utilized to assess the effects of treatments on incidences of fungal disease, on nematode populations, and on grain yields. Treatment sums of squares were partitioned into main effects of aldicarb and fungicides and the interaction between aldicarb and fungicides in a $2 \times 2$ factorial design (Steel and Torrie 1960). Since the variances for each year were homogenous, analyses of variance were conducted on the $3 \mathrm{yr}$ of data with years treated as fixed effects. Covariance analyses (Cochran and Cox 1957) were used to determine if the effects of the fungicide or nematicide treatments on cereal yields were a reflection of their effects on fungal and nematode pathogens.

\section{RESULTS}

Root lesion nematodes were the only endoparasitic nematodes recovered from barley roots and were the dominant 
nematode group recovered from soil. The majority of Pratylenchus spp. (>95\%) were identified as $P$. penetrans, while the remainder were classified as $P$. crenatus Loof. Merlinius spp., Tylenchorhynchus spp. and Paratylenchus spp. also were recovered from soil frequently, but at low population levels $\left(\leq 500\right.$ nematodes $\mathrm{kg}^{-1}$ soil). Nematodes in the orders Rhabditida and Dorylaimida were detected at low levels, and not identified to genus or species. It was also determined that the dominant fungal species on foliage was Pyrenophora teres. Cochliobolus sativus and Fusarium spp. were the dominant fungi on roots.

The severity of common root rot was not reduced by the chemical treatments (Table 1). Disease symptoms were more apparent as the growing season progressed with overall 3 -yr mean ratings of $27.3,51.3$ and $72.3 \%$ at ZGS $30-32$, 55-60, and 70-72, respectively. Foliar diseases were suppressed by the fungicide treatments $(P \leq 0.05)$, and aldicarb reduced the numbers of root lesion nematodes $(P<0.05)$. The average grain yields were about $30 \%$ higher $(P \leq 0.05)$ when both aldicarb and fungicides were applied. Hectolitre and 1000-kernel wt also responded to the treatments. There were effects of year for all categories $(P \leq 0.05)$ except for numbers of nematodes in roots. In the analyses of covariance, the use of nematodes $\mathrm{g}^{-1}$ total root system or $\mathrm{kg}^{-1}$ soil, or \% root rot rating or \% leaf disease as covariates did not change levels of significance.
Aldicarb treatments reduced $(P \leq 0.05)$ the numbers of root lesion nematodes in crown and seminal roots in all but a few instances just before harvest (Table 2). The fungicide treatments, except in one case, did not affect nematode populations. Nematode numbers were greater $(P \leq 0.05)$ in seminal roots than in crown roots during the early and middle part of the growing season. The mean nematode levels in seminal and crown roots were 6700 and 580,2490 and 630 , and 450 and 450 nematodes $\mathrm{g}^{-1}$ dry root for ZGS 30-32, 55-60 and 70-72, respectively.

Of the 506 statistical comparisons involving root lesion nematodes in the crown and seminal roots systems vithin the various disease categories and sample dates in 1989 and 1990, 271 were significant $(P \leq 0.05)$ and positive (Table $3)$. Correlation coefficients between numbers of nematodes in crown or seminal roots and nematodes in total root systems (crown and seminals combined), and between numbers of nematodes in crown or seminal roots and numbers of nematodes in soil in spring or at harvest were usually positive and often significant $(P \leq 0.05)$. Conversely, correlation coefficients between numbers of nematodes in either of the two root systems and the different yield parameters were usually negative and often significant $(P \leq 0.05)$. There were no definite trends in the correlation coefficients between numbers of nematodes in crown and seminal roots and the root rot or net blotch data.

Table 1. Effect of chemical treatments on severity of fungal diseases, nematode populations, and grain yields of barley $(1988,1989$, and 1990 combined)

\begin{tabular}{|c|c|c|c|c|c|c|c|}
\hline \multirow[b]{3}{*}{ Treatment } & \multirow{2}{*}{\multicolumn{2}{|c|}{ Disease severity ${ }^{a}$}} & \multirow{2}{*}{\multicolumn{2}{|c|}{ Root lesion nematodes }} & \multicolumn{3}{|c|}{ Grain characteristics } \\
\hline & & & & & \multirow[b]{2}{*}{$\begin{array}{c}\text { Total yield } \\
\left(\mathrm{kg} \mathrm{ha}^{-1}\right)\end{array}$} & \multirow[b]{2}{*}{$\begin{array}{l}\text { Hectolitre wt } \\
(\mathrm{kg})\end{array}$} & \multirow{2}{*}{$\begin{array}{l}\text { 1000)-kernel } \\
\text { dry wt } \\
\text { (g) }\end{array}$} \\
\hline & $\begin{array}{c}\text { In roots } \\
(\%)\end{array}$ & $\begin{array}{c}\text { On foliage } \\
(\%)\end{array}$ & $\begin{array}{c}\text { In soil } \\
\left(\text { no. } \mathrm{kg}^{-1}\right)\end{array}$ & $\begin{array}{l}\text { In roots } \\
\left.\text { (no. } g^{-1}\right)\end{array}$ & & & \\
\hline Check & 50.6 & 28.4 & 5250 & 1740 & 2980 & 60.4 & 35.7 \\
\hline Aldicarb (A) & 46.8 & 30.2 & 1480 & 130 & 3310 & 61.4 & 35.1 \\
\hline Fungicides $(F)$ & 47.2 & 26.0 & 5140 & 1350 & 3170 & 60.3 & 37.6 \\
\hline$A+F$ & 47.9 & 17.7 & 890 & 140 & 3860 & 63.7 & 35.6 \\
\hline $\operatorname{SEM}^{b}(n=12, d f=27)$ & 1.36 & 3.25 & 410 & 110 & 100 & 0.36 & 0.82 \\
\hline Significant factors ${ }^{c}(P \leq 0.05)$ & - & $\mathrm{F}$ & $A$ & $A$ & $A, F, A \times F$ & $A, F, A \times F$ & $\mathrm{~F}$ \\
\hline
\end{tabular}

a Arcsine transformations.

b Standard error of the mean; $n=8$ and $\mathrm{df}=18$ for disease severity on foliage.

${ }^{c} \mathrm{~F}$ indicates a difference between plots treated with fungicides and plots without fungicides; $A$ indicates the same procedure for aldicarb; $A \times F$ indicates a significant interaction in the: $2 \times 2$ factorial experiment. 
Table 2. Effect of chemical treatments on numbers of nematodes in crown and seminal roots of barley according to severity classes of root rot diseases (1989 and 1990 combined)

\begin{tabular}{|c|c|c|c|c|c|c|c|c|}
\hline \multirow[b]{3}{*}{ Treatment } & \multicolumn{8}{|c|}{$\begin{array}{l}\text { Root lesion nematodes in roots } \\
\qquad\left(\text { No. } \mathrm{g}^{-1}\right)\end{array}$} \\
\hline & \multicolumn{2}{|c|}{ Healthy ${ }^{a}$} & \multicolumn{2}{|c|}{ Slight } & \multicolumn{2}{|c|}{ Moderate } & \multicolumn{2}{|c|}{ Severe } \\
\hline & Crown & Seminal & Crown & Seminal & Crown & Seminal & Crown & Seminal \\
\hline \multicolumn{9}{|l|}{ Zadoks Growth Stages 30-32 } \\
\hline Check & 970 & 10420 & 1440 & 14260 & 1170 & 7590 & - & - \\
\hline Aldicarb $(A)$ & 230 & 1820 & 180 & 1240 & 120 & 490 & - & - \\
\hline Fungicides $(F)$ & 810 & 11780 & 1090 & 17580 & 350 & 12590 & - & - \\
\hline$A+F$ & 110 & 1220 & 160 & 1020 & 380 & 320 & - & - \\
\hline $\mathrm{SEM}^{b}(\mathrm{n}=8, \mathrm{df}=18)$ & 100 & 1395 & 160 & 1770 & 350 & 4480 & - & - \\
\hline Significant factors ${ }^{c}(P \leqslant 0.05)$ & A & A & A & A & - & A & - & - \\
\hline \multicolumn{9}{|l|}{ Zadoks Growth Stages 55-60 } \\
\hline Check & 1370 & 4790 & 1570 & 8220 & 1920 & 6310 & 510 & 1290 \\
\hline A & 180 & 520 & 210 & 360 & 230 & 340 & 130 & 190 \\
\hline $\mathrm{F}$ & 850 & 4790 & 1200 & 6820 & 830 & 3240 & 400 & 720 \\
\hline$A+F$ & 180 & 780 & 280 & 920 & 110 & 420 & 100 & 150 \\
\hline $\operatorname{SEM}\langle n=8, d f=18)$ & 150 & 1180 & 230 & 630 & 130 & 820 & 170 & 370 \\
\hline Significant factors $(P \leqslant 0.05)$ & A & A & A & A & $A, F$ & $A$ & A & A \\
\hline \multicolumn{9}{|l|}{ Zadoks Growth Stages 70-72 } \\
\hline Check & 810 & 300 & 870 & 1380 & 940 & 1020 & 1200 & 720 \\
\hline A & 140 & 140 & 140 & 130 & 120 & 160 & 100 & 110 \\
\hline$F$ & 460 & 470 & 560 & 620 & 730 & 910 & 610 & 580 \\
\hline$A+F$ & 100 & 220 & 130 & 140 & 130 & 170 & 160 & 110 \\
\hline $\operatorname{SEM}(n=8, d f=18)$ & 210 & 120 & 140 & 390 & 130 & 480 & 190 & 230 \\
\hline Significant factors $(P \leqslant 0.05)$ & A & - & A & A & A & - & A & - \\
\hline
\end{tabular}

Table 3. Relation between nematodes in roots, and between nematodes in roots and incidences of fungi or yield data in barley for 1989 and 1990

\begin{tabular}{|c|c|c|c|}
\hline \multirow[t]{2}{*}{$\begin{array}{l}\text { Correlation between nematodes } \\
\text { in roots and parameters below }\end{array}$} & \multirow[t]{2}{*}{$\begin{array}{l}\text { Total number of } \\
\text { comparisons }^{b}\end{array}$} & \multicolumn{2}{|c|}{$\begin{array}{l}\text { Number of significant correlations } \\
(P \leq 0.05, \mathrm{df}=14)\end{array}$} \\
\hline & & Positive & Negative \\
\hline Nematodes in roots & 506 & 271 & 4 \\
\hline Nematodes in total root ${ }^{\mathrm{c}}$ & 46 & 28 & 0 \\
\hline Nematodes in soil in spring & 46 & 0 & 0 \\
\hline Nematodes in soil at harvest & 46 & 21 & 0 \\
\hline Grain yield & 46 & 0 & 10 \\
\hline 1000-kernel wt & 46 & 0 & 2 \\
\hline Hectolitre wt & 46 & 1 & 16 \\
\hline Mean root rot & 46 & 5 & 0 \\
\hline Net blotch ${ }^{d}$ & 23 & 1 & 0 \\
\hline
\end{tabular}


The number of nematodes in the total root mass (crown and seminal roots combined) at harvest in 1988 were negatively correlated with grain yield data $(-0.619, P \leq 0.05)$. In 1989, the numbers of root lesion nematodes in the total root mass at harvest were positively correlated with the mean of root rot ratings taken at ZGS 30-32, 55-60 and 70-72 (0.522, $P \leq 0.05)$, and negatively correlated with plant emergence counts on 4 July $(-0.653$, $P \leq 0.01$ ). In 1990, the numbers of root lesion nematodes in soil correlated with hectolitre wt $(-0.526, P \leq 0.05)$. Also in 1990 , the mean of root rot ratings taken at ZGS 30-32, 55-60 and 70-72 were negatively correlated with hectolitre wt $(-0.568, P \leq 0.05)$ and with 1000-kernel wt $(-0.585, P \leq 0.05)$. In the same year, root rot ratings acquired at ZGS $70-72$ were negatively correlated with hectolitre wt $(-0.667, P \leq 0.01)$, and net blotch ratings recorded at ZGS 30-32 were negatively correlated with grain yields $(-0.531$, $P \leq 0.05)$.

\section{DISCUSSION}

The yield responses that occurred when aldicarb and fungicides were applied indicated that root lesion nematodes and the fungi which incite root rot and net blotch were important factors in yield losses of barley. However, the use of variables such as nematodes $\mathrm{g}^{-1}$ root in the total root system, nematodes $\mathrm{kg}^{-1}$ soil, root rot and net blotch severity as covariates in the analyses of covariance did not change the levels of significance. This may be interpreted to indicate that factors other than root lesion nematodes and fungal species may also have affected yields. These factors may have been abiotic ones, such as soil temperature and moisture, not monitored in this study.

Root lesion nematode populations were greater in seminal than in crown roots of barley. The likely reasons for such distribution are that seminal roots develop prior to crown roots and are the only roots available; and that plant nematodes are attracted to and thrive in metabolically active roots of suitable hosts (Wallace 1963), and it is generally accepted that seminal roots of cereals are physiologically more active than crown roots
(Brouwer 1966). Root lesion nematodes interfere with the movement of water in potato and tobacco roots (Kimpinski 1979; Odihirin 1971), and the same effect may also occur in seminal roots of barley. However, once crown roots develop, the importance of seminal roots declines (Henry and Deacon 1981), and the impact of parasites and pathogens in these roots on the host plant would be expected to decline.

The investigation of relationships between population levels of root lesion nematodes and incidence and severity of root rot or net blotch in barley indicated the relative degree to which the components were correlated. Such correlations do not indicate causality, but they do infer that biological interactions were occurring between the nematodes in different root systems, i.e. crown and seminal, and between nematodes in the same root systems at different sampling times. This statement originated from 506 correlation coefficients involving root lesion nematodes in the two root systems, of which 271 were positive and significant $(P \leq 0.05)$. The same observation was made for Cochliobolus sativus. Consistent positive and significant $(P \leq 0.05)$ correlations between mean root rot ratings from all sampling dates in each year and the ratings at each sampling date indicated that the population of a root pathogen on a barley plant would influence populations of the same fungal species later in the growing season (data not shown).

There were only a few significant correlations $(P \leq 0.05)$ between nematodes, either in crown or seminal roots, or in the total root system, and the incidence and severity of common root rot or net blotch. These observations agree with previous studies in the region (Kimpinski et al. 1987, 1989). However, the significant interacting responses of grain yield and hectolitre dry wt indicated that the aldicarb and fungicides treatments did not act independently. When factors are not independent of each other, further experimentation may be warranted (Steel and Torrie 1960). More quantitative measurements of the population levels of fungal species, and less reliance on disease symptom ratings, could help to elucidate biological interactions that may exist 
between root lesion nematodes and fungal pathogens in cereal diseases.

The use of fungicides for disease control in barley can be profitable to growers in the Maritime region (Johnston and MacLeod 1987). However, nematicides are too expensive for use in cereals when applied at recommended rates for vegetable and potato crops (Kimpinski and Thompson 1990). Lower rates of nematicides applied to cereals, as was done in Australia (Brown etal. 1982, Gurner etal. 1980), might be an option forgrowers in the Maritime region, but more investigation is needed.

\section{ACKNOWLEDGEMENTS}

We thank Dr. K.B. McRae, Agriculture and Agri-Food Canada, Research Centre, Kentville, Nova Scotia and Mr. J.B. Sanderson, Agriculture and Agri-Food Canada, Research Centre, Charlottetown, Prince Edward Island for statistical advice, and Mr. C.E. Gallant and Mr. W.B. MacMicken, Agriculture and Agri-Food Canada, Research Centre, Charlottetown, Prince Edward Island for technical assistance.

\section{REFERENCES}

Andersen, H.J. 1975. [Pratylenchus spp. (Nematoda)-populasjonsdynamik ved ensiding bygdyrking] (in Danish). Nord. Jordbrugsforsk. $57: 1129-1130$.

Barker, K.R. 1985. Nematode extraction and bioassays. Pages 19-35 in K.R. Barker, C.C. Carter, and J.N. Sasser (eds.), An advanced treatise on Meloidogyne, Volume II: Methodology. North Carolina State Univ. Graphics, Raleigh, North Carolina.

Benedict, W.G., and W.B. Mountain. 1956. Studies on the etiology of a root rot of winter wheat in southwestern Ontario. Can. J. Bot. 34: 159-174.

Bergeson, G.B. 1972. Concepts of nematodefungus associations in plant disease complexes: a review. Exp. Parasitol. 32: 301-314.

Brouwer, R. 1966. Root growth of grasses and cereals. Pages 153-166 in F.L. Milthorpe and J.D. Ivins (eds.), The growth of cereals and grasses. Butterworth, London.
Brown, R.D.,D.L. Pye, and G.T.Stratford. 1982. A comparison of low volume, in-row applications of nematicides at seeding for control of the cereal cyst nematode (Heterodera avenae) in wheat. Nematol. Mediterr. $10:$ 9-19.

Clough, K.S., and H.W. Johnston. 1978. Cereal diseases in the Maritime Provinces, 1977. Can. Plant Dis. Surv. 58 : 97-98.

Cochran, W.G., and G.M. Cox. 1957. Experimental designs. Wiley, New York. $611 \mathrm{pp}$.

Gurner, P.S., A.J. Dube, and J.M. Fisher. 1980. Chemical control of cereal cyst nematode (Heterodera avenae) on wheat by a new low-volume applicator. Nematologica $26: 448-454$.

Henry, C.M., and J.W. Deacon. 1981. Natural (non-pathogenic) death of the cortex of wheat and barley seminal roots, as evidenced by nuclear staining with acridine orange. Plant Soil $60: 255-274$.

Hooper, D.J. 1986. Extraction of nematodes from plant material. Pages 51-58 in J.F. Southey (ed.), Laboratory methods for work with plant and soil nematodes : reference book 402, HMSO, London.

Horsfall, J.G., and E.B. Cowling. 1978. Pathometry: the measurement of plant disease. Pages 120-136 in J.G. Horsfall and E.B. Cowling (eds.), Plant disease: an advanced treatise, Vol. 2. Academic Press, New York.

Johnston, H.W. 1976. Influence of spring seeding date on yield loss from root rot of barley. Can. J. Plant Sci. 56 : 741-743.

Johnston, H.W., and J.A. MacLeod. 1987. Response of spring barley to fungicides, plant growth regulators, and supplemental nitrogen. Can. J. Plant Pathol. 9 : 255-259.

Kimpinski, J. 1979. Root lesion nematodes in potatoes. Am. Potato J. 59 : 79-86.

Kimpinski, J., and L.S. Thompson. 1990. Plant parasitic nematodes and their management in the Maritime provinces of Canada. Phytoprotection 71: 45-54.

Kimpinski, J., H.W. Johnston, and R.A. Martin. 1987. Influence of aldicarb on root lesion nematodes, leaf disease and root rot in wheat and barley. Plant Pathol. $36: 333-338$.

Kimpinski, J., R.V. Anderson, H.W. Johnston, and R.A. Martin. 1989. Nematodes and fungal diseases in barley and wheat on Prince Edward Island. Crop Prot. 8: 412416. 
Ledingham, R.J., T.G. Atkinson, J.S. Horricks, J.T. Mills, L.J. Peining, and R.D. Tinline. 1973. Wheat losses to common root rot in the Prairie Provinces of Canada 1969-1971. Can. Plant Dis. Surv. 53 : 113-122.

Martin, R.A. 1985. Disease progression and yield loss in barley associated with net blotch, as influenced by fungicide seed treatment. Can. J. Plant Pathol. $7: 83-90$.

Odihirin, R.A. 1971. Effects of root-knot and lesion nematodes on transpiration and water utilization by tobacco plants. J. Nematol. 3 : 321-322 (Abstract).

Steel, R.G.D., and J.H. Torrie. 1960. Principles and procedures of statistics. McGraw-Hill Book Co. Inc., New York 481 pp.
Sylvester-Bradley, R., J.P. Grills, and J.F. Roebuck. 1985. Methods for measuring cereal crops. Pages 213-239 in Aspects of applied biology 10. Association of Applied Biologists, Wellesbourne, Warwick, U.K.

Wallace, H.R. 1963. The biology of plant parasitic nematodes. Edward Arnold, London. $280 \mathrm{pp}$.

Zadoks, J.C., T.T. Chang, and C.F. Konzak. 1974. A decimal code for the growth stages of cereals. Weed Res. $14: 415-421$. 